\title{
KONSEP PENDIDIKAN RASULULLAH DAN REFLEKSI PADA KOMPETENSI HOLISTIK SAHABAT
}

\author{
Zulherma ${ }^{1}$, Tafiati ${ }^{1}$, Sumiati ${ }^{1}$, Novizal Wendry ${ }^{1}$ \\ ${ }^{1}$ Universitas Islam Negeri Imam Bonjol, Padang \\ *Corresponding Address: zulherma@gmail.com
}

Naskah diterima: 6 Agustus 2021| Disetujui: 30 Agustus 2021 | Diterbitkan: 1 September 2021

\begin{abstract}
This research was conducted with the background of studying the role of the Prophet as an educator. The aim of the study was to find out how the Prophet played a role as an educator which was analyzed from the achievements in the lives of the companions who became students of the Prophet and have been educated holistically, by teaching education with strategies, methods and curriculum sourced from Allah, so that the competence of cognitive (head), dexterity (hand) and heart are maximized and holistically become abilities for their students. This research method is a literature study, the researcher conducts a study of a number of references related to books, journals, and reading sources related to this research, especially analyzing various reference sources related to the Prophet as an educator and various achievements of the companions (sahabah), whose names are stated in a hadith. The results of this study conclude that there is a holistic competence in the practice of the lives of the companions and Rasulullah is a teacher who has educated his students with holistic competences which is reflected in the various achievements of sahabah in their lives.
\end{abstract}

Keywords: rasulullah; competence; holistic; sahabat

\begin{abstract}
Abstrak: Penelitian ini dilakukan atas latar belakang pendalaman studi tentang peran Rasulullah sebagai seorang edukator atau pendidik. Penelitian memiliki tujuan untuk menemukan bagaimana Rasulullah berperan sebagai pendidik berdasarkan prestasi-prestasi yang dilakukan dalam kehidupan para sahabat yang menjadi murid Rasulullah dan telah didik secara holistik. Dengan konsep pendidikan Rasulullah baik strategi, metode, sikap terbaik guru dan murid dalam proses Pendidikan, serta kurikulum yang bersumber dari Allah sehingga memunculkan kompetensi daya pikir (head), kecekatan (hand), dan hati (heart) yang maksimal. Secara holistik berbagai konsep ini menjadi kompetensi bagi murid-muridnya. Metode penelitian ini adalah studi pustaka, peneliti melakukan analisis terhadap sejumlah referensi terkait buku-buku, jurnal-jurnal, maupun bacaan yang yang menelaah topik terkait dengan topik yang dilakukan dalam penelitian ini, terutama menganalisis berbagai referensi-referensi dengan tema Rasulullah sebagai pendidik dan referensi yang mengangkat berbagai prestasi para sahabat yang namanya tercantum dalam salah satu hadis sahiah. Hasil penelitian ini menyimpulkan bahwa adanya kompetensi holistik dalam praktik kehidupan para sahabat dan Rasulullah merupakan seorang guru yang telah mendidik muridnya dengan kemampuan menyeluruh yang terefleksi dalam sikap-sikap dan amalan para sahabat selama mereka mereka menjalani kehidupan mereka.
\end{abstract}

Kata kunci: rasulullah; kompetensi; holistik; sahabat open access article under the CC BY-SA 4.0 license. DOI: 10.37680/qalamuna.v13i2.909 


\section{PENDAHULUAN}

Muhammad Shalallahu Alaihi Wassalam (saw), merupakan utusan Allah atau Rasulullah yang dikenal memiliki prestasi unggul dalam berbagai aspek dan ruang lingkup kehidupan yang dijalaninya. Hal tersebut diakui oleh banyak sejarawan. Dalam buku History of Turkey karya (Lamartine, 1854), Muhammad saw diakui seorang ahli filsafat, ahli pidato, juru dakwah, ahli hukum, ahli strategi perang, cendekiawan, pelopor dalam berpikir rasional, populer tanpa rekayasa, seorang penakluk 20 (dua puluh) buah kerajaan bahkan juga menguasai satu kekuasaan atau kerajaan spiritual yakni Islam. Pengarang buku tersebut juga menguatkan pernyataannya pada akhir tulisannya dalam bukunya. Sang pengarang menulis pertanyaan retoris terkait Muhammad saw. "Jika di analisis semua kriteria dalam mengukur prestasi seorang individu manusia, kita mungkin bertanya apakah ada orang yang lebih hebat dari orang ini?”. Penulis lain seperti, Al-Zamakhsyari \& Ibnu Umar, juga telah memberikan pengakuan bahwa Muhammad saw adalah sosok yang sangat patut diikuti serta kehidupannya wajib diteladani oleh setiap Muslim (Al-Zamakhsyari \& Ibnu Umar, 1977), pada tafsirnya al Kasysyaf. Muhammad saw, nabi dan utusan Allah pencetus munculnya peradaban besar dunia (John L, 2004). Nabi Muhammad merupakan tokoh yang berada pada deretan pertama dalam urutan manusia yang memiliki pengaruh paling signifikan dalam sejarah keberadaan manusia. Namun, selain hal itu Rasulullah juga merupakan seorang guru yang memiliki keunggulan dalam mendidik para sahabat dan umat (Hart, 1989). dalam Rasulullah adalah seorang pendidik profesional yang menguasai materi, strategi mengajar yang efisien serta efektif serta memiliki akhlak mulia sebagai penunjang kemampuannya tersebut(Anas, 2017). Hal ini, menurut (Antonio, 2018), merupakan hal yang tidak biasa bagi karakter individu biasa, mengingat Muhammad saw dibesarkan tanpa kehadiran seorang bapak yang membimbing dan mengarahkan. Rasulullah juga tidak mendapatkan bimbingan edukasi formal sebagaimana mestinya. Rasulullah tidak pernah terdaftar sebagai pelajar pada pusat-pusat pendidikan Yunani di bawah bimbingan filosof yang ada pada waktu itu, tapi pada momentum kehidupannya pada akhirnya Rasulullah mampu mengangkat derajat kaumnya dengan ilmu pengetahuan yang terdapat pada ajaran Islam.

Rasul menciptakan peserta didik yang luar biasa, bahkan beberapa sahabat Rasul yang dijamin sukses dunia dan akhirat, yang diriwayatkan dalam salah satu hadis Rasulullah. Ilmu pengetahuan yang Rasulullah miliki merupakan ilmu langsung yang ditransfer oleh Zat yang Maha Berilmu pengetahuan yakni, Allah. Allah Swt memberikan wahyu dengan arahan spiritual sehingga nilai-nilai mulia terimplementasi pada aspek pendidikan dalam agama Islam dan menjadi pencerah bagi peradaban manusia yang gelap gulita (Haq, 2010). Kehidupan masyarakat Arab pra Islam adalah masyarakat yang memiliki kebiasaan meminum khamar, melakukan taruhan-taruhan, pergaulan bebas laki-laki dan perempuan, menyembah berhala bahkan mengubur hidup anak perempuannya 
karena dianggap sebagai suatu aib yang memalukan karena menganggap perempuan sebagai makhluk hina dan bangsa Arab memiliki kebanggaan terhadap kelompok dan keturunan (Hitti, 2010).

Di tengah fenomena tersebut, ajaran atau pendidikan Islam datang ingin mencerahkan. Pendidikan Islam datang dengan aturan tata sikap (akhlak), hukum (syariat), serta aturan-aturan, yang diajarkan oleh seorang Rasul yang mulia. Pribadi Rasul mengajar dengan keunggulan pemikiran dan tindakan. Allah Swt bahkan berfirman yang jika diterjemahkanan secara bebas berbunyi sebagai berikut:

Dialah Allah Zat yang memilih utusan (Rasul) kepada kaum yang buta huruf dari kalangan mereka sendiri, yang membacakan kepada mereka ayat-ayat-Nya, membersihkan rohani mereka dan mengajarkan kepada mereka kitab suci dan alhikmah, walaupun sebelumnya, mereka benar-benar dalam kesesatan yang nyata. (A1 Jumu'ah [62]: 2)

Rasulullah mengajarkan kitab dan hikmah kepada umat, inilah pengakuan Al-Qur'an akan kedudukan Rasulullah sebagai seorang guru, bahkan dalam hadis juga diriwayatkan bahwa Rasulullah merupakan seorang guru dan menyatakan bahwa dia di utus Allah sebagai seorang mu'alim atau pendidik.

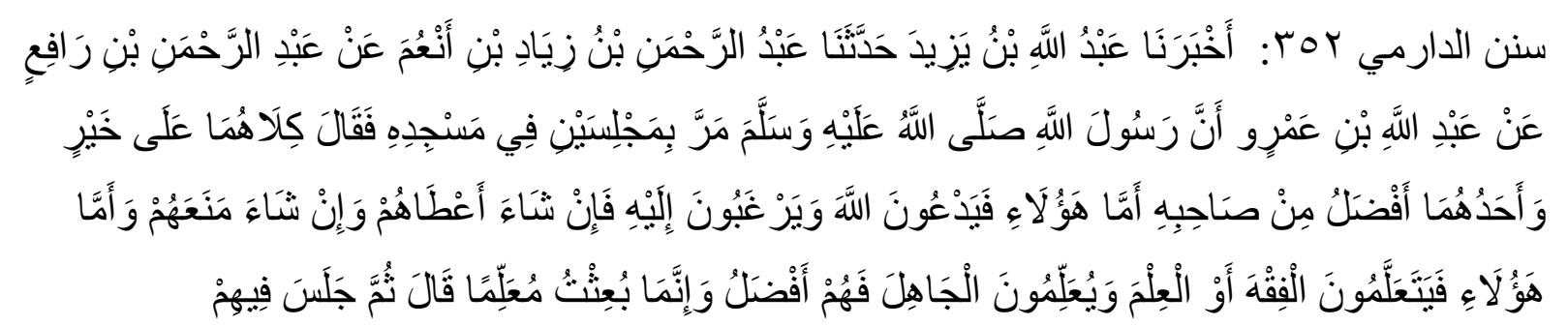

Hadis tersebut telah diriwatkan Ibnu Majah dalam sunan-nya, Ad-Darimi dalam sunan-nya, redaksinya milik Ibnu Majah, dari Abdullah bin Amru bin Al-Ash. Dia berkata bahwa telah menceritakan kepada kami [Bisyr bin Hilal Ash Shawwafi] berkata, telah menceritakan kepada kami [Dawud bin Az Zibirqan] dari [Bakr bin Khunais] dari [Abdurrahman bin Ziyad] dari [Abdullah bin Yazid] dari [Abdullah bin 'Amru] ia berkata; Pada suatu hari Rasulullah saw keluar dari salah satu kamarnya dan masuk ke dalam masjid. Lalu beliau menjumpai dua kelompok jamaah, yang salah satunya tengah membaca Al Qur`an dan berdo'a kepada Allah. Kelompok satunya sedang melakukan proses belajar mengajar. Maka Nabi saw pun bersabda:

"Masing-masing berada di atas kebaikan, mereka membaca Al Qur`an dan berdo`a kepada Allah maka jika Allah menghendaki akan memberinya dan jika tidak menghendakinya maka tidak akan memberinya. Dan mereka yang sedang mempelajari dan mengajarkan ilmu, sementara diriku di utus sebagai pendidik," lalu beliau duduk bersama mereka. (HR. Ibnu Majah) (Majah, n.d.). 
Hadis tersebut kembali mempertegas kedudukan Rasulullah sebagai pendidik, untuk itu peneliti melakukan penelitian studi pustaka ini dengan tujuan mendalami kompetensi Rasulullah sebagai seorang pendidik mencerahkan pemikiran umat dari kebodohan (jahil) kepada kondisi beradab dan berilmu dalam masa dua puluh tiga tahun, dan hal tersebut adalah perubahan yang revolusioner dalam sejarah umat manusia. Di mana hal tersebut dapat dilihat dari prestasi dan amalan sepuluh sahabat yang dijamin dalam sebuah hadis akan meraih kesuksesan di akhirat dengan kepastian jaminan surga, yang berbunyi sebagai berikut:

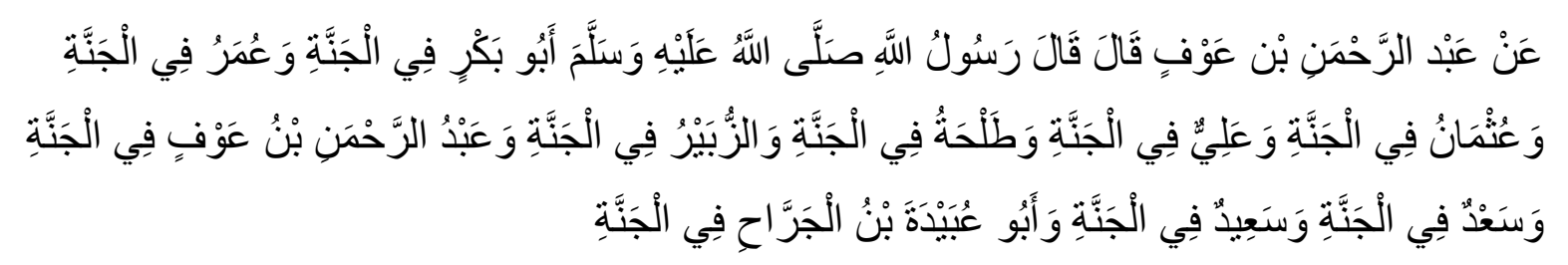

Artinya: Abu Bakar di surga, Umar di surga, Utsman di surga, Ali di surga, Thalhah di surga, Az-Zubair di surga, 'Abdur-Rahman bin 'Auf di surga, Sa'ad bin Ab̄̄ Waqqās di surga, Sa'id bin Zaid di surga, Abu Ubaidah bin al-Jarrah di surga. (HR. Ahmad, Tirmidzi dan An-Nasai).

Rasulullah dalam mendidik mengarahkan para peserta didik untuk memiliki kompetensi holistik. Kompetensi holistik adalah kemampuan unggul dan berprestasi pada ranah kognitif atau daya pikir (head), keterampilan (hand), dan perasaan (heart).

\section{METODE}

Library Research atau studi pustaka adalah penelitian yang dikategorikan berdasarkan tempat penelitian yang antara lain terdapat tiga jenis yaitu, field research, laboratory research dan library research. Pada library research data penelitian berasal dari referensi pustaka. Studi ini menggali sepenuhnya dari pengkajian literatur. Metode penelitian dalam studi literatur merupakan rangkaian kegiatan yang terkait dengan pengumpulan data dari berbagai kepustakaan, kegiatan membaca dan mencatat serta mengelola data tersebut sebagai bahan penelitian yang dengan pendekatan tertentu akan dianalisis agar dapat ditarik kesimpulan (Zed, 2008). Studi pustaka dalam penelitian ini untuk mengetahui kompetensi holistik Rasulullah sebagai pendidik. Dalam analisis data agar dapat ditafsirkan dengan akurasi yang tepat peneliti menggunakan pendekatan (Miles \& Huberman, 1992). Hal ini dilakukan dengan cara reduksi terhadap data yang ada, melakukan sajian dari data, serta melakukan penarikan kesimpulan. Miles dan Huberman berpendapat bahwa pada saat penarikan kesimpulan dari sajian data adalah merupakan bagian aktifitas dari konfigurasi utuh dalam melakukan pendekatan analisis data. Hal ini agar penyimpulan akhir itu tidak hanya dilakukan pada saat proses pengumpulan data saja, tetapi ada verifikasi lagi sehingga dapat dipertanggung jawabkan hasil riset ini sebagai studi ilmiah. 


\section{HASIL DAN PEMBAHASAN}

\section{Rasulullah sebagai Guru}

Drisko menyatakan dalam menilai seorang yang profesional harus dilakukan dan ditujukan kepada kemampuan keseluruhan dari kegiatan profesionalnya, bukan hanya kompetensi pada elemenelemen tertentu saja. Studi ini akan menganalisis Rasulullah sebagai insan yang memiliki karakter terjaga dan mampu menyebarkannya kepada peserta didiknya. Akhlak Rasulullah dalam surat Al Qalam ayat keempat, Allah berfirman bahwa Muhammad saw sungguh memiliki budi pekerti yang agung. Hal ini merupakan poin keunggulan sejati Muhammad saw yang lahir sebagai keturunan Arab di tanah Arab, Makkah. Terkait informasi bangsa Arab sebelum kedatangan Islam, belum ditemukan referensi akurat mengenai hal ini. Penyebabnya menurut Syarifuddin, karena gaya hidup bangsa Arab yang mengembara dan juga karena belum adanya kekuatan politik yang kuat sehingga sejarah belum menuliskan, dan tidak ditemukan dokumen valid terkait peta kekuatan bangsa Arab sebelum kedatangan Islam.

Nabi Muhammad merupakan salah satu dari keturunan suku Quraisy, mereka merupakan kalangan aristokrat terpandang kota Makkah. Keturunan Quraisy disegani oleh seluruh suku-suku yang ada di tanah Arab. Rasulullah saw merupakan anak dari ayahandanya Abdullah bin Abdul Muthalib dan ibundanya Aminah binti Wahab. Terkait garis keturunan Nabi Muhammad yang berasal dari keturunan nabi Ismail terdapat sebuah hadis Muslim dan Tirmidzi yang mengambil perkataan dari Watsilah bin Asyqo yang menyatakan bahwa Rasulullah pernah berkata bahwa:

"Sesungguhnya Allah telah menentukan Kinanah merupakan keturunan dari Ismail serta Allah juga memilih kaum Quraisy merupakan keturunan Kinanah. Allah menentukan bahwa Bani Hasyim berasal dari suku Quraisy serta Allah juga telah menentukan aku dari keluarga Bani Hasyim."

Dari pihak ayahnya Abdullah, Nabi Muhammad merupakan cicit dari Hasyim yang merupakan asal keturunan dari Bani Hasyim. Keturunan ini adalah penanggung jawab baitullah (Ka'bah). Hasyim merupakan ayah dari Abdul Muthalib, kakek Nabi Muhammad saw, keturunan Bani Hasyim berasal dari Hasyim bin Abdu Manaf bin Qushay. Bani Hasyim merupakan bagian dari Suku Quraisy, keturunan dari Fihr bin Malik bin Al Nadhr bin Kinanah. Menurut sebagian sejarahwan Bani Hasyim merupakan bagian dari Bani Kinanah. Kinanah sendiri merupakan keturunan dari Adnan. Lengkapnya Kinanah bin Khuzayma bin Mudrikah bin Ilyas bin Mudhar bin Nizar bin Ma'ad bin Adnan. Garis keturunan Rasulullah saw, hanya diketahui hingga Adnan. Sehingga ulama-ulama mau pun penulis Sirah Nabawiyah menyimpulkan bahwa nasab Adnan ujungnya adalah Ismail bin Ibrahim AS. Nabi Muhammad terlahir sebagai anak yatim dan bahkan menjadi yatim piatu ketika masih kecil, sehingga ini membuat Muhammad ikut bekerja membantu Abu Thalib pamannya, yang 
mengasuhnya. Muhammad kecil mengembalakan ternak agar dapat membantu pamannya. Pada usia remaja, Muhammad dibawa pamannya ikut berdagang hingga ke berbagai kota di Arab dan Afrika, seperti kota Basrah dan Ethopia. Aktivitas-aktivitas perdagangan ini terus digeluti Muhammad hingga usia dewasa. Menurut Malahayati, sewaktu berumur dua belas tahun Rasulullah telah diajarkan berdagang oleh pamannya Abu Thalib hingga ke negara lain dan yang pertama dikunjungi adalah antara lain Syria, Jordania, dan Lebanon.

Pada rentang usia remaja, antara 17 tahun hingga 20 tahun, beliau telah melakukan perdagangan yang menurut relasi dan rivalnya diakui memiliki kematangan dalam perhitungan dagangnya, memiliki kejujuran serta memiliki karakter sebagai saudagar yang profesional. Popularitas Nabi Muhammad saw akhirnya sampai pada saudagar wanita Makkah yakni Khadijah. Khadijah melakukan kontrak kerja dengan bayaran perbulan sebesar harga empat ekor unta. Bisnis terus berlanjut menempuh negara-negara yang merupakan jalur dagang utama pada waktu itu, yaitu Yaman, Syam melintasi Madyan, dan Wadil Qura. Muhammad saw yang terkenal jujur sehingga dipanggil sebagai al-Amin (orang yang dipercaya). Hal tersebut menjadi daya tarik bagi masyarakat Arab. Keuntungan-keuntungan dagang yang diperoleh melebihi dari keuntungan para kongsi-kongsi dagang lainnya. Pada masa melakukan perdagangan banyak sikap Rasulullah yang menunjukkan kompetensi yang holistik. Sikap-sikap yang telah teruji pada jalur realitas, yang secara konsep akan menjadi materi pendidikan yang holistik tersebut. Terkait karakter utama Rasulullah yang menjadi modal bagi kesuksesannya dalam dunia dagang, yakni kejujuran. Shiddiq bersikap benar, tidak terlintas untuk menjual barang yang cacat, yang mungkin dengan segala tipu muslihat akan laku. Sikap terpercarya atau amanah. Sikap ini diakui oleh para relasi dan konsumennya.

Selanjutnya karakter fathanah yaitu karakter seorang yang cerdas serta karakter seorang guru yaitu, tabligh atau menyampaikan. Rasulullah mampu membangun komunikasi serta menjadikan bisnis sebagai wadah dalam melakukan tarbiyah. Khadijah tertarik untuk mengajak Muhammad berkerjasama. Kerjasama yang terus melahirkan kemajuan-kemajuan dan terus berkembang. Muhammad yang fathanah terus mendapatkan dukungan Khadijah hingga mereka menikah.

Rasulullah menerima amanah kenabian dan kerasulan pada usia empat puluh tahun, Khadijah termasuk yang pertama menerima kerasulan Nabi Muhammad. Kerasulan ini terjadi melalui perantara malaikat Jibril dengan turunnya wahyu dari Allah yang pertama di Gua Hira. Khadijah merupakan wanita Arab yang ikut berdagang dan berkarier dalam ranah publik. Ummul Mukminin dari awalnya merupakan sosok pedagang yang tangguh serta memiliki kemampuan manajemen bisnis yang baik. Khadijah tampil menentang adat istiadat Arab yang memiliki tradisi kalau perembuan hanya semata di rumah dan urusan perdagangan mutlak milik kaum lelaki. Khadijah r. a., bahkan melakukan 
transaksi dan perjalanan untuk urusan perdagang hingga melintasi negaranya, melakukan hubungan dagangan internasional ke negara Syam atau Syria serta beberapa perdagangan mancanegara lainnya sekitar abad ke- enam Masehi. Menjadi istri utusan Allah telah memposisikan suaminya Muhammad saw otomatis sebagai seorang guru bagi umat manusia yang wajib menyampaikan apa yang diterimanya dan mengajarkan kepada umat. Muhammad melakukan seruan dakwah ini dimulai dari orang-orang terdekatnya dan seterusnya kepada kaumnya sendiri, yaitu suku Quraisy. Perjuangan dakwah Nabi Muhammad saw diyakini dan diterima istrinya Khadijah, keponakannya Ali bin Abi Thalib, seterusnya Abu Bakar Shiddiq, Utsman bin Affan, Umar bin Khattab, Thalhah, Zubair, Khamzah, Muawiyah serta pengikut dari kelompok kaum miskin yang tidak populer. Muhammad saw berdakwah pada situasi dan kondisi yang sulit untuk embasmi sikap mental, sosial dan budaya yang pada waktu itu tidak sesuai dengan nilai-nilai religi.

Pertentangan yang amat berat dan sengit datang dari paman-paman Nabi, yaitu Abu Lahab dan Abu Jahal, bahkan mereka tak hanya menolak, namun sangat anti terhadap ajaran Muhammad. Tekanan demi tekanan kalangan Quraisy kepada Muhammad dan kaum miskin yang berpihak pada ajaran Muhammad menyebabkan para pengikutnya terpaksa pindah ke daerah Ethopia sedangkan Rasulullah hijarah ke daerah Thaif, namun di sana Rasul juga mendapatkan respon yang hampir sama. Penolakan yang tindakan tak menyenangkan, bahkan dizalimi warga hinga sempat terluka.

Khadijah dan Rasulullah telah bersama dalam perjuangan mereka selama 24 tahun. Dalam umur 64 tahun 6 bulan, istri pertama Rasulullah ini wafat. Beliau menghembuskan nafas terakhir di gunung Hujun karena sakit dan lemah dalam perjuangan karena adanya pemblokadean yang dilakukan kaum Qurais dalam rentang waktu tiga tahun. Khadijah dimakamkan di sebuah pemakaman yang dekat dengan kota Makkah. Tahun meninggalnya dikenal sebagai Amul Huzni atau Tahun Dukacitanya Rasulullah. Rasulullah terus memantapkan dakwah secara perlahan dan rahasia, hingga suasana penolakan mulai berubah menjadi penerimaan yang tulus dari tiga belas orang jamaah haji dari Yatsrib (sekarang Madinah) di Aqabah.

Pada saat rutinitas pelaksanaan haji tahunan, Rasulullah selalu bersilaturahmi ke kemah-kemah jamaah haji yang berkunjung ke Makkah. Walaupun awalnya sedikit yang menerima kunjungan silaturahmi Rasulullah kecuali sebahagian kecil rombongan haji yang menerima secara antusias yaitu jamaah haji dari Yatsrib dan kabilah Khazraj. Jamah haji ini berbait setia kepad Rasulullah bahkan berjanji untuk ikut menyebarkan dakwah yang dibawa Nabi. Baiatul Aqabah pertama ini kemudian dilanjutkan tahun berikutnya yaitu dua. Perjanjian warga Yastrib ini menjadi semacam kontrak sosial politik pertama yang selanjutnya menjadi faktor munculnya pengakuan dan sikap kenegarawan Nabi Muhammad di Madinah, kedatangan 73 orang jamaah haji tersebut untuk melakukan pertemuan dan 
baiat berjanji setia dengan Nabi. Mereka berbaiat untuk mengabdi kepada Allah Swt. Berjanji untuk tidak menzalimi hak orang lain, tidak akan melakukan pergaulan bebas, dan tidak akan membunuh anak-anak, serta menjaga diri dari amalan keji. Mereka berjanji untuk setia kepada Rasulullah serta berjanji tidak akan durhaka jika menemukan hal yang tidak sejalan dengan ajaran Islam. Jamaah haji juga memohon agar Muhammad saw mau menjadi pemimpin mereka dan pindah Yatsrib. Alasan warga Yastrib meminta Nabi hijrah karena ada tiga faktor utama.

Pertama, adanya informasi dari warga Yahudi bahwa akan lahir Rasul Allah. Faktor kedua adanya penindasan kaum Yahudi pada suku Aus dan khazraj, faktor ketiga pertikaian antara dua suku, Auz dan suku Khazraj yang telah bertikai dalam rentang waktu lama merindukan kedatangan pimpinan yang mampu mendamaikan mereka. Rasulullah saw kemudian mengutus sahabatnya Mush'ab bin Umair berdua dengan 'Amr bin Ummi Maktum ke Yatsrib untuk mengajar para pengikut nabi Muhammad saw ajaran Agama Islam, Al Qur'an, shalat dan lain sebagainya.

Inilah langkah yang meluaskan Islam keluar dari Makkah. Penerimaan dari warga Yatrib ini menyebabkan perjuangan Rasulullah mulai diterima, walaupun perjuangan masih sangat berat. Hijrah ke Madinah kian menampakkan kecemerlangan sosok Muhammad saw dalam berbagai sepak terjang aktivitas yang Rasulullah hadapi, Rasulullah menjadi populer dan buah bibir semua kalangan waktu itu.

\section{Muhammad saw sebagai Pendidik Revolusioner}

Rasulullah dalam mendakwahkan Islam selama dua puluh tiga tahun mulai dari nol hingga mampu menguasai sebagian besar negara-negara di bawah panji Islam, kurun yang sangat pendek, sehingga keberhasilan Rasul bisa dikatakan revolusioner dalam sejarah umat manusia dan hal ini tidak bisa lepas dari sosok Rasulullah yang dalam segala hal mampu menjadi yang terbaik. Rasul merupakan teladan yang karena hal itu dalam waktu yang relatif singkat banyak masyarakat Arab tertarik ingin dididik dengan ajaran yang Rasulullah usung. Rasulullah memiliki potensi-potensi superior termasuk sebagai pendidik. Muhammad saw merupakan seorang anak yatim, yang tidak mendapatkan pendidikan resmi membaca dan menulis dan Rasulullah tidak mendapatkan ilmu dari pusat belajar resmi Yunani yang diasuh para filosof. Dalam Kenyataannya Rasulullah memiliki kemampuan memecahkan masalah-masalah yang muncul dan mengatasi dengan cara yang bijak dan cerdas. Rasulullah telah diberikan pendidikan langsung oleh Allah karena Allah menurunkan utusanNya para rasul dan nabi untuk mempraktekan agar nilai pendidikan yang pada hakikatnya untuk manusia, agar kehidupan dapat dijalankan dengan lebih mudah. Allah berfirman dalam Al-Qur'an terkait kemampuan Rasul, Allah telah mengirim utusan Rasul-Nya ke teruntuk kaum yang tak mengenal tulis baca, yakni utusan dari kaum mereka sendiri untuk membacakan kepada mereka ayat- 
ayat Allah, serta menyucikan (jiwa) mereka dan memberikan mereka pelajaran berupa Kitab dan Hikmah (Sunnah), meskipun sebelumnya, mereka benar-benar dalam kesesatan yang nyata (Al Jumu'ah [62]: 2). Dalam hadis juga diriwayatkan bahwa Rasulullah merupakan seorang guru dan pembimbing yang arif dan bijaksana dan menekankan pentingnya pendidikan dalam rangka meningkatkan kualitas manusia. Dalam sebuah hadis dari Imam Muslim yang meriwayatkan hadis ini dalam kitab Talak tentang kisah, Nabi Muhammad saw menyuruh para istrinya memilih dan nabi meminta dari 'Aisyah pertama untuk memilih. Maka ia, 'Aisyah RA. Telah menetapkan memilih Rasulullah, Aisyah meminta agar Nabi tidak mengatakannya kepada (istri) Rasul yang lain. Selanjutnya hal ini membuat Rasulullah bersabda:

Sesungguhnya Tuhan tidak menugasiku untuk melakukan pemaksaan kepada seseorang atau menjerumuskan seseorang, akan tetapi Allah menyuruhku menjadi seorang pendidik yang yang bertugas memberikan kemudahan dalam urusan manusia (HR Muslim).

Menganalisis sikap Rasulullah dalam konsep pendidikan yang Rasul terima para sejarahwan mendapatkan bahwa ada tiga strategi yang Rasul lakukan secara fleksibel agar dakwah yang Rasul usung bisa bergerak. Dakwah diawali dengan diterimanya wahyu pertama surat Al-Alaq oleh Rasulullah. Strategi pendidikan yang Rasulullah lakukan dalam dakwahnya adalah secara individual dan sembunyi-sembunyi. Jika kita analisis sejarah maka lembaga pendidikan Islam atau sekolah Islam pertama adalah rumah seorang sahabat yang bernama Arqam bin Arqam. Penyebaran ajaran Islam dilakukan secara rahasia selama tiga tahun untuk menghindari konflik dan pelarangan dari mereka yang tidak suka. Dakwah yang dilakukan secara terang-terangan dan terbuka di mulai dengan turunya perintah Allah. Rasul lalu mengumpulkan keluarga dekatnya di bukit Shafa. Rasul meminta para kerabatnya untuk takut akan kerasnya azab yang Allah sediakan di akhirat bagi manusia yang tidak mau untuk mengakui bahwa Allah adalah Tuhan yang satu serta Muhammad sebagai Rasulullah. Namun, seruan ini dibantah pamannya Abu Jahal bahkan beliau memarahi Muhammad karena mengumpulkan para kerabat hanya untuk hal yang dianggap sebagai hal yang tidak penting. Strategi ketiga adalah untuk masyarakat luas. Surat al-Hijr [15]:94-95 menjadi penguat tindak lanjut strategi Rasulullah berikutnya, menyebarkan ajaran secara lebih luas.

Dalam tata sikap guru dalam proses belajar mengajar menurut Rasulullah saw harus mampu membuat siswa tertarik (Tin, 2020). Hal ini berdasarkan hadis yang bersumber dari sahabat Rasulullah Anas bin Malik. Dari Nabi saw bersabda: "mudahkan dan jangan dipersulit, beri kabar gembira jangan sampai kabur (membuat orang lari)." Hadis ini memberi penjelasan untuk, "jangan mempersulit", hadis ini juga menegaskan perlunya "mempermudah", khususnya dalam mendidik dan mengajarkan suatu ilmu pengetahuan. Ungkapan "sampaikan kabar gembira" dipasangkan dengan 
kalimat, "jangan membuat orang lari". Hal ini menekankan perlunya seorang guru untuk selalu memberikan kabar baik dan tidak menakut-nakuti peserta didik atau murid-muridnya. Hadis ini memberi perintah pada para guru untuk mengambil dan menarik hati orang lain, terkait dengan masalah ilmu dan Islam, dan tidak bersikap kasar terhadap mereka. Kedua, bersikap tegas tetapi tidak keras. Seorang guru atau instruktur mungkin menunjukkan ketegasannya, terkait dengan pelajaran yang disampaikan. Guru diperbolehkan membuka ruang untuk para peserta didiknya menanyakan apa saja yang mereka belum mengerti, atau mungkin informasi lain yang akan menambah pemahaman dan wawasan mereka. Dalam tata sikap siswa dalam proses belajar adalah, duduk dengan tenang di majelis ilmu. Sikap peserta didik, murid atau santri seperti ini, dapat diketahui dari hadis yang artinya "Dari Abu Waqid Al Laitsi, bahwa Nabi saw sedang duduk di masjid di masjid bersama para sahabatnya datang tiga orang. Dua orang itu menghadap Nabi saw dan yang lainnya pergi, kedua orang itu terus duduk bersama Nabi saw di mana salah satu dari mereka tampak bahagia untuk berdiskusi dengan Nabi saw sementara yang kedua duduk di belakang mereka, yang ketiga berbalik pergi, setelah Nabi saw selesai berdiskusi, dia berkata: "Maukah Anda memberi tahu saya tentang tiga orang tadi?” Nabi menjawab, “Adapun salah satunya, dia meminta perlindungan kepada Allah, maka Allah melindunginya. Kedua, dia malu kepada Allah, maka Allah pun malu padanya. Sedangkan yang ketiga berpaling dari Allah kemudian Allah berpaling darinya". Hadits ini menjelaskan tentang adab atau etika saat berada dalam majelis ilmu, diantaranya masuk ke majelis dengan mengucapkan salam terlebih dahulu. Pertama, anjuran untuk membentuk halaqah dalam majelis ilmu. Kedua, anjurkan untuk duduk dekat dengan guru, dan menempati tempat kosong dalam majelis. Ketiga, anjuran untuk menutup celah dalam halaqah, seperti anjuran untuk menutup celah kosong dalam antrean shalat. Keempat, anjuran untuk memberikan pujian kepada orang yang ingin berdesak-desakan dalam mengejar kebaikan. Kelima, larangan keluar dari majelis khususnya bagi umat Islam. Keenam, mementingkan keutamaan hadir dalam majelis ilmu, majelis para orang sholeh, dan majelis nasehat di masjid. Selanjutnya seorang murid harus memperhatikan sepenuhnya pelajaran yang diajarkan. Setiap siswa harus memberikan perhatian penuh terhadap pelajaran yang sedang dipelajari. Rasulullah dalam konsep pendidikannya, juga menggunakan sejumlah metode dalam mendidik sahabatnya. Antara lain dilakukan Rasulullah dalam berbagai yang situasi dan kondisi yang tepat sasaran untuk digunakan (Arief, 2005). Pelaksanaan metode ceramah, Rasulullah gunakan setelah mendapatkan wahyu. Metode ini dapat dengan leluasa memberikan penjelasan rinci terkait wahyu tersebut. Namun, kepada Mu'az bin Jabal yang menjadi hakim, utusan ke negeri Yaman, Rasul menggunakan metode dialog. Dalam keseharian Rasul juga menggunakan metode diskusi dengan cara melakukan tanya jawab, para murid Rasul sering mengajukan pertanyaan tentang sesuatu hal yang mereka tidak tahu, kemudian Rasulullah memberikan jawab atas pertanyaan yang 
dilontarkan tersebut. Metode perumpamaan atau dikenal dengan istilah metode amtsal seperti pada saat memberikan contoh akan kebersamaan kaum yang beriman dibaratkan sebagai satu tubuh yang satu sama lain akan memikul beban yang sama. Metode lain pada beberapa kesempatan juga Rasulullah manfaatkan adalah metode berkisah, metode pembiasaan, serta metode hafalan.

Pada awal menjalankan edukasinya kepada masyarakat Makkah, Rasulullah belum memiliki banyak murid sebagai pengikut. Apalagi terdapat hal-hal yang menambah berat beban tugas mengajar, yaitu adanya penolakan masyarakat Makkah pada waktu itu kepada ajaran yang dibawa Muhammad. Hingga sebagaimana yang telah kita paparkan diatas pendidikan ajaran Islam dilakukan secara sembunyi-sembunyi dan hanya kepada kalangan terdekat (Nizar, 2008).

Pendidikan dapat dinyatakan juga sebagai sebentuk upaya agar dapat membenahi serta menganti karakter buruk kepada karakter yang lebih baik. Dari tradisi jahiliyah atau kebodohan kepada tradisi yang lebih santun dan lebih beradab. Di samping itu semua, para pelajar Muslim harus memahami Islam secara holistik. Pendidikan Islam memiliki dimensi lahir (hand dan head) dan dimensi bathin, berupa spiritual atau heart dalam menyikapi berbagai fenomena dikehidupan. Manusia tidak lengkap jika hanya berbicara iman sabatas pengertian saja atau melaksanakan rukun Islam dalam batasan pengertian yang dangkal saja. Melakukan ritual-ritual yang diperintahkan seperti ibadah sholat, haji, umrah, namun tidak secara mendalam mengambil esensi atau hakikatnya secara rohani. Peserta didik harus secara menyeluruh mempelajari dan menerapkan komponen ilmu dan amal sebagaimana Rasulullah yang merupakan peserta didik langsung dari Allah. Rasulullah, merupakan sosok yang telah dipilih Allah untuk menjadi panutan dan model bagi semua pelajar. Rasul menjadi rujukan bagi umat dan para pelaku dan penyelenggara dunia pendidikan hingga dewasa ini. Rasul juga telah meramu, memetakan dan mengimplementasikan elemen-elemen edukasi yang menjadi faktor pendukung bagi kebutuhan pendidikan sepanjang zaman. Walaupun mungkin ada yang pro dan kotra, menolak dan menerima, namun pengakuan dunia atas keberhasilan Rasulullah dalam mendidik terus mengalir hingga kini. Analisis implementasi pendidikan Rasulullah dalam AlQur'an dapat peneliti paparkan, pertama Rasulullah menyampaikan segala sesuatu sebagai anugerah atau rahmat bagi semua, hal tersebut tercantum dalam Al-Qur'an surat Al Anbiya' ayat 107, dakwah atau ajaran Islam disampaikan untuk semua kalangan. Materi edukasi yang Rasulullah ajarkan bukan rekayasa, pembodohan atau pembohongan, namun benar-benar kebenaran hakiki yang bersumber dari Allah. Rasul juga seorang evaluator yang semuanya merupakan bagian dari aktivitas pendidikan yang beliau lakukan kepada umat, hal tersebut terdapat dalam Al-Qur'an pada surat Al-Syuara' ayat ke 48. Selanjutnya sosok Rasul merupakan uswah hasanah bagi umatnya yang terdapat dalam AlQur'an pada surat Al-Ahzab ayat ke 21(Ramayulis, 2004). 
Tabel 1. Prestasi Sahabat

\begin{tabular}{|c|c|c|}
\hline Nama Sahabat & Pekerjaan & Prestasi \\
\hline $\begin{array}{l}\text { Abu Bakar Ash } \\
\text { Shiddiq. }\end{array}$ & $\begin{array}{l}\text { Berdagang } \\
\text { Khalifah selama } \\
23 \text { Tahun } 10 \text { hari }\end{array}$ & $\begin{array}{l}\text { Pengumpul dan penghimpun Al Qur'an } \\
\text { Tegas dalam memerangi mereka yang murtad dan kikir } \\
\text { dalam membayar zakat. } \\
\text { Periwayat: } 42 \text { buah hadis }\end{array}$ \\
\hline $\begin{array}{l}\text { Umar bin Al } \\
\text { Khathab }\end{array}$ & $\begin{array}{l}\text { Khalifah selama } \\
10 \text { tahun } 6 \text { bulan } 4 \\
\text { hari. }\end{array}$ & $\begin{array}{l}\text { Penakluk negeri Syam, Persia, Irak, Mesir, Sebahagian } \\
\text { Libia, Tripoli bagian barat, Azerbaijan, daerah } \\
\text { Nahawand, daerah Jurjan dan lain sebagainya. } \\
\text { Melakukan percetakan uang bertuliskan kalimah } \\
\text { Alhamdulillah dan Lailaha illa Allah Muhammad } \\
\text { Rasulullah } \\
\text { Meresmikan Penanggalan Islam } \\
\text { Periwayat: } 527 \text { buah hadis }\end{array}$ \\
\hline Utsman bin Affan & $\begin{array}{l}\text { Khalifah selama } \\
11 \text { tahun } 11 \text { bulan } \\
14 \text { hari. }\end{array}$ & $\begin{array}{l}\text { Menyelesaikan pengumpulan Al Qur'an } \\
\text { Membebaskan Afrika, Khurrasan, Armenia, Cyprus, } \\
\text { Tabaristan, Kirman, dan Sajastan serta Qauqaz, } \\
\text { Perluasan Dua Masjid Makkah dan Madinah } \\
\text { Memprakarasai pendirian pangkalan Angkatan Laut } \\
\text { Membentuk kepolisian negara } \\
\text { Membangun Pengadilan } \\
\text { Periwayat } 146 \text { buah hadis }\end{array}$ \\
\hline Ali bin Abi Thalib. & $\begin{array}{l}\text { Khalifah selama } 4 \\
\text { tahun } 8 \text { bulan }\end{array}$ & Periwayat 586 buah hadis. \\
\hline Zubair bin Awwam & Tentara & Periwayat 38 buah hadis. \\
\hline $\begin{array}{l}\text { Sa'ad bin Abi } \\
\text { Waqash. }\end{array}$ & $\begin{array}{l}\text { Gubernur wilayah } \\
\text { Irak }\end{array}$ & Periwayat 271 buah hadis. \\
\hline $\begin{array}{l}\text { Abu Ubaidah bin Al } \\
\text { Jarrah. }\end{array}$ & Tentara & $\begin{array}{l}\text { Pembebas Wilayah Syam } \\
\text { Periwayat } 14 \text { buah hadis. }\end{array}$ \\
\hline
\end{tabular}




\begin{tabular}{|c|c|c|}
\hline $\begin{array}{l}\text { Abdurrahman bin } \\
\text { Auf }\end{array}$ & Saudagar & $\begin{array}{l}\text { Memerdekakan } 30 \text { budak/hari } \\
\text { Dermawan kepada kaum duafa, istri-istri Nabi dan dana } \\
\text { untuk kebutuhan militer } \\
\text { Mewasiatkan } 400 \text { dinar/orang tentara perang Badar. } \\
\text { Memberi wasiat untuk perjuangan di jalan Allah } 1000 \\
\text { ekor kuda dan } 50.000 \text { dinar. } \\
\text { Periwayat } 65 \text { hadis. }\end{array}$ \\
\hline $\begin{array}{l}\text { Thalhah bin } \\
\text { Ubaidillah }\end{array}$ & Dermawan & $\begin{array}{l}\text { Mendermakan seluruh uang miliknya tanpa } \\
\text { meninggalkan sepersenpun. } \\
\text { Periwayat } 38 \text { hadis. }\end{array}$ \\
\hline Sa'id bin Zaid & $\begin{array}{l}\text { Tentara hingga } \\
\text { berusia } 70 \text { tahun }\end{array}$ & Periwayat 48 buah hadis. \\
\hline
\end{tabular}

Sumber: berbagai referensi

\section{Kompetensi Holistik Pendidikan Rasulullah}

Holistic education menurut Sudrajat (2008) adalah bagian dari filsafat pendidikan yang lahir dari pemikiran bahwa setiap individu akan dapat menemukan identitas dirinya, makna hidup serta tujuan hidupnya dari masyarakat, lingkungan alam, dan nilai-nilai rohani.

Etimologi kata dari kompetensi adalah kecakapan atau kompetensi adalah kemampuan yang dimiliki seseorang (Tim Prima Pena, 2006). Terminologi kompetensi bermakna ilmu pengetahuan, skill serta basis nilai-nilai yang terwujud cara pikir dan bertindak seseorang (Mulyasa, 2005). Kekonsistenan dalam kebiasaan berpikir dan bertindak akan membawa seorang individu menjadi kompeten (Majid \& Andayani, 2005).

Uraian di atas memberikan kesimpulan, kompetensi adalah gabungan dari penguasaan ilmu pengetahuan, keterampilan, dan nilai-nilai dasar yang didapatkan dari kekonsistenan mengimplementasikan kemampuan tersebut secara holistik. Pendidikan atau edukasi bermakna tuntunan tumbuh dan berkembangnya seorang anak anak (Ki Hadjar, 1962). Pendidikan adalah sebentuk usaha dalam mengeluarkan kekuatan dari kodratnya yang dimiliki setiap anak manusia, sehingga mereka dapat bertumbuh kembang sebagai individu maupun anggota masyarakat yang memiliki kehidupan yang selamat. Seorang yang disebut pendidik atau guru menurut Islam adalah individu yang mau tanggung jawab akan kemajuan diri dari peserta didiknya dan melakukan stimulus optimal seluruh potensinya secara holistik baik, head, hand dan heart (Nurdin, 2008). Rasulullah dalam suatu hadist juga menyatakan bahwa: 


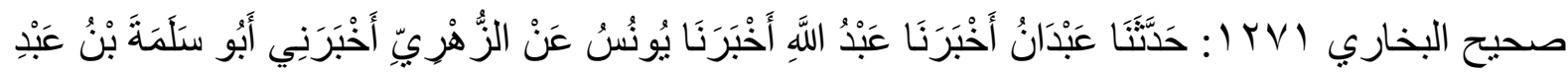

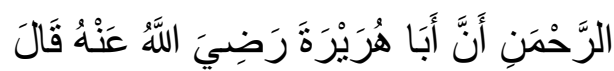

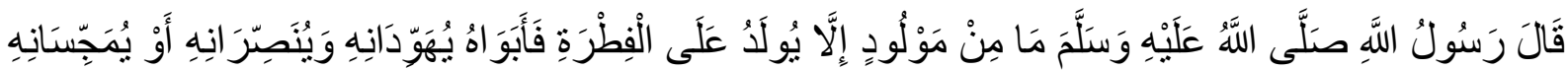

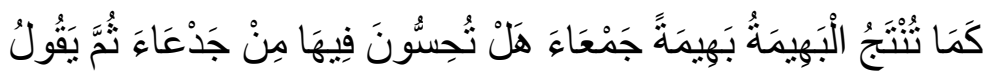

Artinya: Telah menceritakan kepada kami 'Abdan telah mengabarkan kepada kami 'Abdullah telah mengabarkan kepada kami Yunus dari Az Zuhriy telah mengabarkan kepada saya Abu Salamah bin 'Abdurrahman bahwa Abu Hurairah r.a. berkata: Telah bersabda Rasulullah SAW: "Tidak ada seorang anak pun yang terlahir kecuali dia dilahirkan dalam keadaan fitrah. Maka kemudian kedua orang tuanyalah yang akan menjadikan anak itu menjadi Yahudi, Nashrani atau Majusi sebagaimana binatang ternak yang melahirkan binatang ternak dengan sempurna. Apakah kalian melihat ada cacat padanya".

Rasulullah pada hadis di atas menjelaskan peran orangtua edukasi upaya yang dilakukan orangtua dalam membentuk anak-anaknya, berbekal fitrah yang telah diberikan Allah kepada masingmasing manusia. Edukasi merupakan usaha manusia yang lebih dewasa dalam membantu memberikan bimbingan kepada manusia yang belum dewasa menuju kepada kedewasaan mereka, atau upaya membantu anak dalam memahami dan menjalani tugas-tugas hidupnya, supaya lahir sikap mandiri, matang, dan bertanggung jawab secara tata kehidupan normal dan sebaiknya sebagaimana yang diyakini Bersama (Langeveld, 1980)

Jika ditelusuri referensi pendidikan holistik secara teoritis telah dikemukakan oleh beberapa tokoh klasik Barat sejak lama. Tokoh pendidikan Barat yang mengagas pendidikan holistik adalah Friedrich Froebel, Ralph Waldo Emerson, Bronson Alcott, Henry Thoreau, Johann Pestalozzi, Jean Rousseau dan Francisco Ferrer (Sudrajat, 2008). Pemikiran dan gagasan inti dari para perintis pendidikan holistik tersebut sempat tak mendapatkan perhatian dunia pendidikan hingga muncul perubahan paradigma kebudayaan di Amerika pada tahun 1960-an. Pada tahun 1970 mulai muncul kembali gagasan pendidikan holistik.

Konferensi pertama pendidikan Holistik Nasional Amerika yang diselenggarakan oleh Universitas California pada bulan Juli 1979. Enam tahun kemudian, para penganut pendidikan holistik mulai memperkenalkan tentang dasar pendidikan holistik dengan sebutan 3 R's, akronim dari relationship, responsibility dan reverence (Rubiyanto \& Haryanto, 2010). Tujuan pendidikan holistik adalah memudahkan pengembangan potensi individu dalam kondisi pembelajaran yang menyenangkan, demoktaris, humanis, sehingga tak hanya berupa pemberian materi berupa teks pelajaran secara teoritis, yang membebani peserta didik namun melalui pengalaman interaksi secara 
langsung dengan realitas lingkungan. Tujuan pendidikan secara holistik yang menjadi hasil dari seminar ini adalaha bagaimana siswa mampu menjadi dirinya sendiri (learning to be). Bernstein menyatakan, peserta didik tak hanya di doktrin saja dengan banyak ilmu pengetahuan namun juga mendapatkan kebebasan secara psikologis, misalkan dengan kebebasan dalam mengambil keputusan yang terbaik menurut dirinya, bisa belajar dengan tata cara gaya belajarnya, siswa juga memperoleh kecakapan sosial, serta dapat mengembangkan karakter dan emosionalnya secara natural.

Adapun pemikiran Abraham Maslow menyatakan bahwa edukasi harus mampu membuat siswa memperoleh kesempatan untuk mengaktualisasikan dirinya (self-actualization). Hal ini ditandai dengan adanya 4 hal pada diri siswa diantaranya, (1) kesadaran; (2) kejujuran; (3) kebebasan atau kemandirian; dan (4) kepercayaan. Pendidikan secara holistik akan mengakomodasi kebutuhan dan potensi yang dimiliki siswa secara menyeluruh, baik secara intelektual, maupun emosional serta fisik, termasuk juga aspek artistik, kreatif, dan rohaninya. Pada proses ini pembelajaran menjadi tanggung jawab bersama, baik secara personal serta tanggung jawab kolektif, oleh karena itu strategi pembelajaran lebih diarahkan pada bagaimana mengajar dan bagaimana orang belajar. Pertimbangan lain yang juga membantu dalam mengembangkan strategi-strategi dalam pembelajaran holistik adalah melalui pendekatan pembelajaran transformatif serta melakukan prosedur pembelajaran yang fleksibel, pemecahan masalah juga melalui banyak disiplin ilmu, melakukan pembelajaran yang bermakna, dan pembelajaran melibatkan komunitas di mana peserta didik berada.

Dalam pendidikan holistik, peran dan otoritas guru untuk memimpin dan mengontrol kegiatan pembelajaran hanya sedikit dan guru lebih banyak berperan sebagai sahabat, mentor, dan fasilitator. Forbes mengibaratkan peran guru seperti seorang teman dalam perjalanan yang telah berpengalaman dan menyenangkan. Sekolah hendaknya menjadi tempat peserta didik dan guru bekerja guna mencapai tujuan yang saling menguntungkan. Komunikasi yang terbuka dan jujur sangat penting, perbedaan individu dihargai dan kerjasama lebih utama dari pada kompetisi.

Uraian di atas memberikan kita kesimpulan bahwa edukasi adalah tuntunan bagi tumbuh dan berkembangnya seorang anak oleh orang dewasa berbekal fitrah dan kodratnya menjadi peribadi dewasa yang dapat diterima anggota masyarakat. Pendidikan Rasulullah adalah tuntunan bagi tumbuh dan berkembangnya seorang anak. Anak berbekal fitrah dan kodratnya menjadi peribadi dewasa yang dapat diterima anggota masyarakat sesuai dengan tuntunan dari Rasulullah. Kompetensi yang digariskan oleh Rasulullah saw berdasarkan kepada wahyu Allah yang kemudiannya diwariskan ke sahabat yang mengumpulkan, membukukan Al-Qur'an serta hadis, yang selanjutnya berkembang dalam dunia Islam menjadi ilmu-ilmu baru seperti ilmu tafsir, ushuludin, fiqih, dan ilmu-ilmu lain. Kompentensi pendidikan Rasulullah melahirkan sejumlah besar sahabat dalam waktu relatif singkat 
menjadi manusia-manusia yang diharapkan Al Qur'an. Rasul mampu mengajar secara individual dan kolektif dalam mendorong, menganjurkan dan mengajak para sahabat menghapus kebodohan, serta juga mengingatkan mereka dari lemah semangat secara tegas.

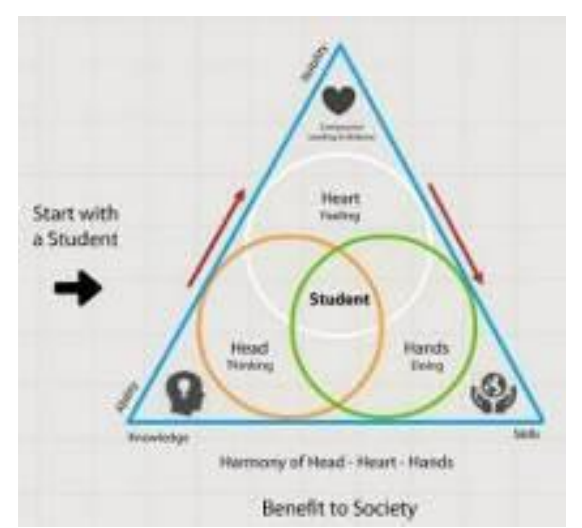

Gambar 1. Ruang Lingkup Kompetensi Holistik

Kompetensi dari pendidikan Islam yang dicontohkan Rasulullah berbasiskan kepada Al-Qur'an dituntut menjadi ajaran yang sesuai dengan akal dan juga sesuai fitrah manusia serta pragmatis. Hasil dari pendidikan yang demikian itu dapat dilihat dari sikap para pengikutnya yang dipancarkan kehidupan. Kurikulum yang diajarkan oleh Rasulullah baik di Makkah ataupun Madinah bertujuan untuk membentuk insan yang sempurna baik secara fisik maupun spiritual untuk memperoleh kebahagian di dunia akhirat. Rasulullah dalam mendidik memperhatikan kompetensi holistik agar peserta didik memiliki kemampuan secara menyeluruh dalam prestasi-prestasi hasil dari praktik dan amalan hidupnya.

\section{KESIMPULAN}

Pendidik adalah seorang yang bertanggung jawab untuk memberikan bimbingan terhadap perkembangan kepribadian dan kemampuan peserta didik baik dengan kompetensi holistik, kompetensi daya pikir (head), keterampilan (hand), dan rasa hati atau perasaan (heart) agar peserta didik mampu berkiprah maksimal, baik secara individu maupun sebagai makhluk sosial. Rasulullah merupakan sosok pendidik yang telah memberikan kompetensi secara holistik kepada peserta didiknya sehingga terefleksi dalam kehidupan mereka. Cerdas pada kehidupan nyata, tangkas di medan-medan perjuangan, serta memiliki perasaan halus dengan banyak aktivitas kemanusiaan dan berbagi bagi kesejahteraan orang lain. 


\section{DAFTAR PUSTAKA}

Al-Zamakhsyari, A. A.-Q. J., \& Ibnu Umar, M. (1977). Al Kasysyaf 'An Haqaiq Al-Tanzil wa Uyun Al-Aqawil fi Wujuh Al-Takwil. Matba'ah Isa Al-Babi Al-Halibi.

Anas, N. (2017). Rasulullah sebagai Pendidik Profesional. Jurnal Pendidikan Islam.

Antonio, M. S. (2018). Muhammad Super Leader, Super Manager. Mutiara Qolbun Salim.

Arief, A. (2005). Sejarah Pertumbuhan dan Perkembangan Lembaga Pendidikan Islam Klasik. Penerbit Angkasa.

Haq, Muhammad Zaairul. (2010). Muhammad saw Sebagai Guru. Kreasi Wacana.

Hart, M. H. (1989). Seratus Tokoh yang Paling Berpengaruh dalam Sejarah. Pustaka Jaya.

Hitti, P. K. (2010). History of the Arabs: From the Earliest Times to the Present (Terj. R. Cecep Lukman Yasin dan Dedi Slamet Riyadi). Serambi Ilmu Semesta.

John L, E. (2004). Ensiklopedi Oxford Dunia Islam Modern (5th ed.). Mizan.

Ki Hadjar, D. (1962). Karja I (Pendidikan). Pertjetakan Taman Siswa.

Lamartine, A. D. (1854). Histoire De La Turquie.: Vol. II. Aux Bureaux Du Constitutionnel.

Langeveld, M. J. (1980). Pedagogik Teoritis dan Sistematis (Terjemahan). Jemmars.

Majah, I. I. (n.d.). Bab Fadlu Al- 'Ulama wa Al-Haththu 'ala Talab Al-'Ilm. Al-Darimi.

Majid, A. \& Andayani. (2005). Pendidikan Agama Islam Berbasis Kompetensi (Konsep dan Implementasi Kurikulum 2004). Remaja Rosdakarya.

Miles, M. B., \& Huberman, M. (1992). Analisis Data Kualitatif. Penerbit Universitas Indonesia.

Mulyasa, E. (2005). Kurikulum Berbasis Kompetensi, Karakteristik dan Implementasi. Remaja Rosdakarya.

Nizar, S. (2008). Sejarah Pendidikan Islam Menelusuri Jejak Sejarah Pendidikan Era Rasulullah Sampai Indonesia. Keneana Prenada Media Group.

Nurdin, M. (2008). Kiat Menjadi Guru Profesional. Ar Ruzz Media.

Ramayulis. (2004). Metodologi Pendidikan Agama Islam. Kalam Mulia.

Rubiyanto, N., \& Haryanto, D. (2010). Strategi Pembelajaran Holistik di Sekolah. Prestasi Pustaka.

Sudrajat, A. (2008, January 26). Pendididkan Holistik [Blog]. Tentang Pendidikan. https://akhmadsudrajat.wordpress.com/2008/01/26/pendidikan-holistik/ 
Tim Prima Pena. (2006). Kamus Ilmiah Populer. Gita Media Press.

Tin, R. (2020). Tin, Rahma. (2020). Education Concept by Rasulullah Shallallahu' Alaihi Wasallam: Analysis of the Hadith Analysis of the Book of Science of Sahih Bukhari. Studia Religia, 4(1). Zed, M. (2008). Metode Penelitian Kepustakaan. Yayasan Obor. 